\title{
Immunity to the G1 Globular Domain of the Cartilage Proteoglycan Aggrecan Can Induce Inflammatory Erosive Polyarthritis and Spondylitis in BALB/c Mice but Immunity to G1 Is Inhibited by Covalently Bound Keratan Sulfate In Vitro and In Vivo
}

\author{
Jean-Yves Leroux, Alexei Guerassimov, Annie Cartman, Nathalie Delaunay, Carolyn Webber, Lawrence C. Rosenberg, \\ Subhashis Banerjee, and A. Robin Poole \\ Joint Diseases Laboratory, Shriners Hospital for Crippled Children and Division of Surgical Research, Department of Surgery, McGill \\ University, Montreal, Quebec, H3G 1 A6 Canada; and *Orthopedic Research Laboratories, Montefiore Medical Center, New York 10467
}

\begin{abstract}
Earlier work from this laboratory showed that the human proteoglycan aggrecan from fetal cartilages can induce a $\mathrm{CD4}^{+}$ $T$ cell-dependent inflammatory polyarthritis in BALB/c mice when injected after removal of chondroitin sulfate chains. Adult keratan sulfate (KS)-rich aggrecan does not possess this property. We found that two $\mathrm{CD}^{+} \mathrm{T}$ cell hybridomas (TH5 and TH14) isolated from arthritic mice recognize bovine calf aggrecan and the purified G1 domain of this molecule, which also contains a portion of the interglobular domain to which KS is bound. These hybridoma responses to G1 are enhanced by partial removal of KS by the endoglycosidase keratanase or by cyanogen bromide cleavage of core protein. KS removal results in increased cellular uptake by antigen-presenting cells in vitro. After removal of KS by keratanase, G1 alone can induce a severe erosive polyarthritis and spondylitis in BALB/c mice identifying it as an arthritogenic domain of aggrecan. The presence of KS prevents induction of arthritis presumably as a result of an impaired immune response as observed in vitro. These observations not only identify the arthritogenic properties of G1 but they also point to the importance of glycosylation and proteolysis in determining the arthritogenicity of aggrecan and fragments thereof. (J. Clin. Invest. 1996. 97:621-632.) Key words: arthritis $\bullet \mathrm{T}$ lymphocytes $\bullet$ keratan sulfate $\bullet$ aggrecan
\end{abstract}

\section{Introduction}

Patients with ankylosing spondylitis, and juvenile and adult rheumatoid arthritis, exhibit $\mathrm{CD} 4^{+} \mathrm{T}$ cell responses to the hu-

This work has been published previously in abstract form (1992. FASEB [Fed. Am. Soc. Exp. Biol.] J. 6:A2004; 1994. Arthritis \& Rheum. 37:S396; and 1995. Transactions of the 41st Annual Meeting of the Orthopaedic Research Society, Orlando, FL).

Address correspondence to Dr. A.R. Poole, Joint Diseases Laboratory, Shriners Hospital, 1529 Cedar Avenue, Montreal, Quebec, H3G 1A6, Canada. Phone: 514-849-6208; FAX: 514-842-5581; E-mail: MDPO@MUSICA.McGILL.CA Subhashis Banerjee's present address is BASF Bioresearch Corporation, Worcester, MA 01605 and Jean-Yves Leroux's present address is Clinical Research Institute, Université de Montréal, Montréal, Quebec, Canada.

Received for publication 22 May 1995 and accepted in revised form 8 November 1995.

J. Clin. Invest.

(C) The American Society for Clinical Investigation, Inc.

0021-9738/96/02/0621/12 \$2.00

Volume 97, Number 3, February 1996, 621-632 man cartilage proteoglycan $(\mathrm{PG})^{1}$ aggrecan $(1,2)$. Injection of the fetal human cartilage PG into BALB/c mice produces a disease which has features of both rheumatoid arthritis and ankylosing spondylitis $(3,4)$. Both an erosive polyarthritis and spondylitis are observed after immunization of mice with PG in complete Freund's adjuvant (CFA) followed by repeated injections of the PG in incomplete Freund's adjuvant (IFA). Adoptive transfer (5) and in vivo T cell subset depletion studies (6) indicate that the disease is mediated by $\mathrm{CD}^{+}$ T cells.

Removal of the chondroitin sulfate (CS) chains from the core protein of human fetal PG markedly increases the efficiency of induction of the disease $(3,4)$. Anti-PG antibody responses are much higher when CS has been removed from PG $(3,4)$. In contrast, adult human PG, which contains large amounts of keratan sulfate (KS) $(7,8)$, seldom induces arthritis, even after removal of CS. This observation suggested to us that the KS, which is covalently bound to the PG core protein, may, like CS, influence the immune responses of PG-reactive T cells.

To investigate this further, two cloned PG-reactive T cell hybridomas, TH5 and TH14, obtained from mice with PGinduced arthritis, were studied. Both the $\mathrm{T}$ hybridomas are $\mathrm{CD}^{+}{ }^{+}, \mathrm{MHC}$ class II-restricted (9). They probably belong to the TH1 subset since they secrete IL-2 but not IL-4. The pattern of antigen responsiveness of the $\mathrm{T}$ cell hybridomas is characterized by reactivities to human fetal and adult PG, bovine fetal PG, the G1 domain of bovine PG, and bovine link protein (LP). TH5 and TH14 recognize different epitopes in the G1 domain of PG. Associated with the G1 domain of PG there is KS but not CS $(10,11)$. The present study shows that KS can significantly inhibit the reactivities of these $\mathrm{T}$ cell hybridomas to these molecules. Removal of KS, or cleavage of $\mathrm{G} 1$ with cyanogen bromide $(\mathrm{CNBr})$ with resultant separation of the peptides bearing these epitopes from KS chain(s), overcomes this inhibition and permits increased uptake and more efficient presentation by antigen-presenting cells (APC). We show that when $\mathrm{G} 1$ alone is injected into $\mathrm{BALB} / \mathrm{c}$ mice it can induce an erosive polyarthritis and spondylitis but only after removal of KS.

1. Abbreviations used in this paper: APC, antigen-presenting cells; $\mathrm{CNBr}$, cyanogen bromide; $\mathrm{CS}$, chondroitin sulfate; G1, G1 domain of aggrecan; GAG, glycosaminoglycan; IFA, incomplete Freund's adjuvant; KS, keratan sulfate; $\mathrm{LP}$, link protein; $\mathrm{NaN}_{3}$, sodium azide; $\mathrm{PG}$, proteoglycan aggrecan; PVDF, polyvinylidene difluoride; SI, stimulation index. 


\section{Methods}

Mice

Female, 6-8-mo-old, BALB/c retired breeder mice were obtained from Charles River Canada (St. Constant, Quebec, Canada). Young female (6-7-wk-old) BALB/c mice (17-20 grams) were used for induction of arthritis.

\section{Reagents}

The following reagents were used: cesium chloride (Terochem Chemicals, Edmonton, Ontario, Canada); guanidine hydrochloride and iodoacetamide, Alcian blue, casein, $\mathrm{CNBr}$, diisopropyl fluorophosphate, PMSF, pepstatin A, and EDTA (Sigma Chemical Co., St. Louis, MO); protease-free chondroitin ABC lyase (EC4.2.2.4), keratanase (Pseudomonas) (EC2.1.103) (Seikagaku America, Rockville, MD); CFA and IFA (Difco Laboratories Inc., Detroit, MI); $\left[{ }^{3} \mathrm{H}\right]$ thymidine $(6.7 \mathrm{Ci} / \mathrm{mmol})$ (ICN Biomedical Canada Ltd., Montréal, Quebec, Canada); Lympholyte M (Cedarlane Laboratories, Hornby, Ontario, Canada); Aurodye, sodium iodide $\left({ }^{125} \mathrm{I}\right)$ (Amersham, Oakville, Ontario, Canada); paraformaldehyde (BDH Chemicals, Ltd., Toronto, Ontario, Canada), 3-(cyclohexylamino)-1-propane sulfonic acid (United States Biochemical Corp., Cleveland, OH); trypsin, $N$-tosyl, L-phenylalanine chloromethyl ketone-treated (Fluka Chemical Corp., Ronkonkoma, NY) or trypsin, type 1 (Sigma Chemical Co.).

\section{Antigens}

$P G$. Human PG preparations were isolated as described previously (3) from 12-20-wk-old human fetuses. Briefly, the epiphyseal and articular cartilages were extracted in $4 \mathrm{M}$ guanidine hydrochloride in the presence of protease inhibitors and the extracts were centrifuged on a cesium chloride density gradient, first under associative and then under dissociative conditions. The high buoyant density PG fractions (A1D1) were isolated and extensively dialyzed against deionized water and lyophilized. Bovine PG was isolated with the same methodology from adult nasal septum. Native PG preparations were dissolved in sterile phosphate-buffered saline (PBS), sterilized by ultraviolet irradiation in a laminar flow hood $(1-2 \mathrm{~h})$ and assayed for protein by Lowry's method (12).

G1 domain of bovine $P G$. This was purified as described previously by tryptic digestion of an aggregate preparation from calf articular cartilage (13) and purification by gel chromatography (9). It includes part of the interglobular domain between G1 and the G2 domain up to the first trypsin cleavage site $\left(\mathrm{R}^{367}\right)$. This fraction was dialyzed extensively against PBS, $0.45-\mu \mathrm{m}$ filter sterilized, and used in vitro. Bovine G1 preparations were used instead of human G1 preparations because of the greater quantities which could be obtained of the former. The $\mathrm{T}$ cell hybridomas described below had earlier been shown to respond as well to bovine fetal PG as to human PG (9).

\section{Digestion of antigens with glycosidases}

PG and G1 were dissolved at $15 \mathrm{mg}$ (dry wt)/ml and $250 \mu \mathrm{g}$ (dry wt)/ $\mathrm{ml}$, respectively, in $0.2 \mathrm{M}$ Tris- $\mathrm{HCl}$ buffer, $\mathrm{pH} 7.4$, containing $80 \mathrm{mM}$ $\mathrm{NaCl}$ and the following protease inhibitors: $1 \mathrm{mM}$ EDTA, $1 \mathrm{mM}$ iodoacetamide, $5 \mu \mathrm{g} / \mathrm{ml}$ of pepstatin, and $2 \mathrm{mM}$ diisopropyl fluorophosphate or $1 \mathrm{mM}$ PMSF. The mixture was digested with either protease-free chondroitin $\mathrm{ABC}$ lyase $(0.2 \mathrm{U} / \mathrm{mg}$ protein) and/or by keratanase $(2 \mathrm{U} / \mathrm{mg}$ protein $/ \mathrm{ml})$ at $37^{\circ} \mathrm{C}$ for $20 \mathrm{~h}(14)$. The reaction was terminated by boiling the mixture for $5 \mathrm{~min}$. The digested samples were then dialyzed against water, dried on a Speed Vac (Savant Instruments, Inc., Hicksville, NY), and redissolved in sterile PBS at desired concentrations. The solutions were $0.45-\mu \mathrm{m}$ filter sterilized and used in the assays. All native PG or G1 preparations used in the antigen presentation assays were similarly boiled for $5 \mathrm{~min}$ and treated the same way before use in the assays, to control for denaturation of the PG/G1 molecules by boiling.

\section{Reduction and alkylation of G1 globular domain}

Reduction and alkylation were performed as before (8).

\section{$\mathrm{CNBr}$ digestion of $\mathrm{G1}$ globular domain}

Purified G1 was treated with $\mathrm{CNBr}$ for $24 \mathrm{~h}$ as described previously (15). Briefly, lyophilized G1 was dissolved in $70 \%$ formic acid at a concentration of $250 \mu \mathrm{g} / \mathrm{ml}$ to which was added $12 \mathrm{mg} / \mathrm{ml}$ of $\mathrm{CNBr}$ dissolved in acetonitrile. The tubes were flushed with nitrogen, sealed, and incubated at room temperature for $24 \mathrm{~h}$. The digestion was terminated by diluting the mixture with 10 times its volume of water. The mixture was dialyzed against water, lyophilized, and stored at $-20^{\circ} \mathrm{C}$. The digested G1 was redissolved in PBS, and 0.45$\mu \mathrm{m}$ filter sterilized before use in vitro.

\section{Radiolabeling of G1 domain}

The purified bovine $\mathrm{G} 1$ was radiolabeled with $\mathrm{Na}^{125} \mathrm{I}$ by the chloramine $\mathrm{T}$ method (16). The radioiodinated G1 was then separated from free iodine on Sephadex G-25 (Pharmacia Biotech Inc., Piscataway, $\mathrm{NJ}$ ). Depending upon the preparation (three were used), its specific activity was in the range of $0.8-7.1 \times 10^{9} \mathrm{cpm} / \mathrm{mg}$.

\section{Gel electrophoresis of antigens}

The antigen preparations were electrophoresed on a $12.5 \%$ SDSPAGE mini-gel (Bio-Rad Laboratories, Richmond, CA) or on a continuous $5-15 \%$ gradient SDS-PAGE mini-gel, under reducing conditions as described previously (17). After electrophoresis, the proteins were electrotransferred $(60 \mathrm{~V}, 300 \mathrm{~mA})$ for $75 \mathrm{~min}$ in $10 \mathrm{mM}$ 3-(cyclohexylamino)-1-propane sulfonic acid, $\mathrm{pH} 11$, buffer containing $10 \%$ methanol, onto a polyvinylidene fluoride (PVDF) membrane. The membrane was then stained for total protein content using Aurodye gold staining according to the manufacturer's protocol, or stained for glycosaminoglycan (GAG) chains using Alcian blue, or used for immunoblotting as below.

\section{Immunoblotting of antigens}

The membrane was immunoblotted with the mouse mAb 1C6 ( $\left.\operatorname{IgG}_{1}\right)$ which is specific for a repeating epitope in the G1 and G2 regions (18), or with mouse Ab AN9P1 ( $\left.\operatorname{IgG}_{2 \mathrm{a}}\right)$ (16) and mAb 5D4 ( $\left.\operatorname{IgG}_{1}\right)$ (19) specific for KS chains. Briefly, the PVDF membrane was blocked with $3 \%$ BSA in PBS for $1 \mathrm{~h}$ and individual lanes were cut out. The lanes were incubated with the different antibodies for $1 \mathrm{~h}$ at room temperature with shaking, followed by three washes in PBS/ $0.1 \%$ Tween 20 for $5 \mathrm{~min}$. Rabbit anti-mouse IgG (Zymed Laboratories, Inc., South San Francisco, CA) was then incubated with the membranes at room temperature for $1 \mathrm{~h}$ followed by three washes in PBS $/ 0.05 \%$ Tween 20 . The specific antibody binding was visualized by addition of ${ }^{125}$ I-protein A (Amersham) followed by autoradiography.

\section{Assays for proteolytic degradation of antigens}

Casein assay. Casein was radiolabeled according to the method of Cawston and Barrett (20). The assay was essentially the same as described previously (21). The ${ }^{3} \mathrm{H}$-labeled casein was diluted with cold casein to a specific activity of $2.6 \times 10^{6} \mathrm{cpm} / \mathrm{mg}$. The keratanase preparation $(0.5 \mathrm{U})$ to be tested for proteolytic activity was mixed with $200 \mu \mathrm{g}$ of radiolabeled casein in $100 \mathrm{mM}$ Tris/acetate, $50 \mathrm{mM} \mathrm{NaCl}$, $\mathrm{pH} 7.3$, in a total volume of $250 \mu \mathrm{l}$, in the presence of protease inhibitors (as in keratanase digestion experiments using G1, see above). The mixture was incubated for $18 \mathrm{~h}$ at $37^{\circ} \mathrm{C}$, and the digestion was terminated by adding $100 \mu \mathrm{l}$ of unlabeled "carrier" casein $(5 \mathrm{mg} / \mathrm{ml})$ and $150 \mu \mathrm{l}$ of $10 \%(\mathrm{wt} / \mathrm{vol})$ of cold TCA. The tubes were centrifuged at $7,000 \mathrm{~g}$ at $4^{\circ} \mathrm{C}$ for $15 \mathrm{~min}$, and aliquots of supernatants were counted in a liquid scintillation counter (Packard Instruments, Meriden, CT). Radiolabeled casein digested with trypsin $(5 \mu \mathrm{g} / \mathrm{ml})$ was used as a positive control for digestion, and counts with digestion buffer alone served as background control.

Assay for degradation of ${ }^{125} \mathrm{I}-\mathrm{G} 1$. The radiolabeled G1 was digested with keratanase as above and divided into two fractions. One was electrophoresed on a $12.5 \%$ SDS-PAGE gel along with undigested radiolabeled G1 and autoradiographed. The second fraction was precipitated with TCA (as above) and the supernatants were col- 
lected as in the casein assay and counted in a gamma counter (LKBWallach, Turku, Finland).

\section{Sequence analysis of G1 globular domain}

The purified bovine $\mathrm{G} 1$ fragments generated by $\mathrm{CNBr}$ digestion or by endo Asp-N were resolved by SDS-PAGE mini-gel (12.5\% gels) and electroblotted onto PVDF membranes, as described earlier (22). The membranes were stained with Coomassie brilliant blue R-250 in 50\% methanol for $15 \mathrm{~min}$ and destained in 50\% methanol, $10 \%$ acetic acid until the bands could be visualized. The bands were cut out and loaded on a gas phase protein sequenator (model 470A) attached to phenylthiohydantoin amino acid analyzer (model 120A; both from Applied Biosystems, Inc., Foster City, CA). The phenylthiohydantoin-amino acid derivatives were separated by reverse-phase HPLC using a C18 column $(220 \times 2.1 \mathrm{~mm})$.

\section{Aggrecan-reactive T cell hybridomas}

The generation of two PG-reactive T cell hybridomas TH5 and TH14 has been described earlier (9). Briefly, spleen cells from arthritic mice were cyclically stimulated in vitro with PG and feeder cells. PG-reactive T cells were fused with BW5147 thymomas (kindly provided by Dr. P. Marrack, Denver, CO) to produce PG-reactive T cell hybridomas (23). These were cloned and two hybridomas TH5 and TH14 were used for further studies. They were shown previously to be reactive with aggrecan, bovine G1, and LP (9).

\section{Antigen presentation assays}

Antigenic reactivity. All assays were performed in DME with $100 \mathrm{U} / \mathrm{ml}$ penicillin, $100 \mathrm{mg} / \mathrm{ml}$ streptomycin, $2 \mathrm{mM}$ L-glutamine, $0.1 \mathrm{mM}$ nonessential amino acids, $1 \mathrm{mM}$ sodium pyruvate (Gibco Laboratories, Burlington, Ontario, Canada), $50 \mathrm{mM}$ 2-mercaptoethanol (BDH Chemicals, Ltd.), and 5\% heat-inactivated FCS (Bockneck Ltd., Rexdale, Ontario, Canada). The $\mathrm{T}$ cell hybridomas were tested for their reactivities against antigens by incubating $2 \times 10^{4}$ cells/well with $5 \times 10^{5}$ freshly isolated irradiated $(3.3 \mathrm{~Gy})$ syngeneic spleen cells in quadruplicate with various antigens in a total volume of $200 \mu \mathrm{l} /$ well, in 96-well flat-bottomed tissue culture plates (Falcon Labware, Lincoln Park, $\mathrm{NJ}$ ) at $37^{\circ} \mathrm{C}$ for $24 \mathrm{~h}$ with $5 \% \mathrm{CO}_{2}$ and $95 \%$ air. All antigen concentrations were expressed as nanomolars of protein as described previously (9). The supernatants $(100 \mu \mathrm{l} /$ well) were harvested $24 \mathrm{~h}$ later and assayed for IL-2 in an IL-2-dependent mouse cytotoxic T cell line, CTLL-2 (American Type Culture Collection, Rockville, MD), proliferation assay $(24)$, by $\left[{ }^{3} \mathrm{H}\right]$ thymidine uptake as described before (9). All results are expressed as either mean cpm \pm SEM or stimulation index (SI) (mean cpm with antigen/mean cpm with medium alone) of the CTLL cells. The standard errors of at least triplicate determinations were ordinarily $<15 \%$ of the mean.

The $\mathrm{T}$ cell hybridomas were also tested for reactivity to $\mathrm{CNBr}$ peptides of G1 bound to PVDF membrane after separation on SDSPAGE (25). Briefly, the membranes were blocked with PBS $/ 0.3 \%$ Tween 20 for $30 \mathrm{~min}$ at $37^{\circ} \mathrm{C}$ with shaking. The membranes were then washed three times in PBS/0.3\% Tween 20 (5 min each wash), rinsed thoroughly in water, and stained with Aurodye for $2-18 \mathrm{~h}$. The visualized bands were cut into small pieces of $2 \mathrm{~mm}^{2}$, sterilized under ultraviolet light for 30-60 min, and added to the wells for the assays of T cell reactivity.

Use of fixed APC. In some experiments, syngeneic spleen cells were used as APC after fixation in 1\% paraformaldehyde in PBS for $30 \mathrm{~min}$ at room temperature, followed by three washes in Hanks' balanced salt solution.

\section{Uptake and degradation by APC of radiolabeled G1 with or without treatment with keratanase}

Spleen cells from normal mice were used as a source of APC as described above (Antigen presentation assays) with the exception that the cells were not irradiated. Cells $\left(5 \times 10^{6}\right)$ in $0.5 \mathrm{ml}$ DME complete culture medium with $5 \%$ FCS described above were added to borosilicate glass tubes $(13 \times 100$ mm; Fisher Scientific Co., Pittsburgh, PA).
Radiolabeled G1 (native or G1 treated with keratanase) at $1 \times 10^{5}$ $\mathrm{cpm} / 10^{6}$ cells was added to each tube, mixed, and incubated at $37^{\circ} \mathrm{C}$ for periods up to $475 \mathrm{~min}$. The incubation was terminated by adding an equal volume of cold $\mathrm{PBS} / 0.1 \%$ sodium azide $\left(\mathrm{NaN}_{3}\right)$ and centrifuging the cells at $250 \mathrm{~g}$ for $5 \mathrm{~min}$. Cell pellets were washed twice in $\mathrm{PBS} / 0.1 \% \mathrm{NaN}_{3}$ and then counted in the gamma counter. To investigate binding to cell surfaces as opposed to endocytosis, cells were isolated at different times, washed as above, and treated with trypsin $\left(5 \times 10^{6}\right.$ cells were treated with $1 \mathrm{ml}$ of $0.05 \%$ trypsin [Sigma, type I] in PBS for $10 \mathrm{~min}$ at $37^{\circ} \mathrm{C}$ ) to remove cell surface-bound molecules before isolation. In other experiments, we inhibited endocytosis by culturing cells with or without $0.1 \% \mathrm{NaN}_{3}$ which was added 10 min before the addition of radiolabeled G1.

In further experiments we washed the APC twice with $\mathrm{PBS} / 0.1 \%$ $\mathrm{NaN}_{3}$ as described above to remove unbound G1 after incubation for 30 min with radiolabeled $\mathrm{G} 1 \pm \mathrm{KS}$ and then examined the digestion and rate of loss of radiolabel from these cells with time up to $120 \mathrm{~min}$. At each time after binding of radiolabeled G1 to APC, cells were treated with $4.5 \%$ TCA to precipitate any undigested radiolabeled G1. TCA soluble counts were also measured.

\section{Induction of arthritis}

Arthritis was induced in BALB/c mice as described earlier with some modifications (6). Briefly, mice were immunized with either $100 \mu \mathrm{g}$ (protein) of adult nasal bovine PG (native or chondroitinase ABC and/or keratanase digested) or $25 \mu \mathrm{g}$ (protein) of "native" calf articular G1 or G1 treated with keratanase. Some animals were injected with mixtures of two antigens at the same time: $100 \mu \mathrm{g}$ of bovine adult nasal PG mixed with either $25 \mu \mathrm{g}$ of native or keratanasetreated mature G1 (G1-KS). First injections (intraperitoneal) were given as an emulsion of CFA $(100 \mu \mathrm{l})$ with $100 \mu \mathrm{l}$ of antigen solution, followed by intraperitoneal boosts of the same amount of each antigen in IFA at 15, 43, 71, and $99 \mathrm{~d}$ after the first injection. The injections were stopped when arthritis first appeared and persisted. Otherwise they continued for up to a maximum of five injections. PG was injected in the same way at days $7,28,56$, and 84 after the initial injection. Mixtures of G1 and PG were injected according to the PG schedule.

\section{Clinical characterization of arthritis}

Mice were examined for clinical signs of arthritis every second day as described previously (6). Briefly, front and rear paws and ankles were examined for swelling, redness, and limitation of movement. Severity scores were determined on a scale of 0 to 4 for each front paw and rear paw and ankle as follows: grade 1 , mild redness and swelling in one or more joints; grade 2, moderate redness and swelling in involved joint(s); grade 3, severe redness and swelling involving the whole paw; grade 4, grade 3 followed by loss of movement in the affected joints. The sum of arthritic scores in all four paws (maximum 16) was taken as the severity score of the mouse.

\section{Histology}

Fore and hind paws, ankles, knees, and spines were fixed in $10 \%$ buffered formalin, decalcified, and stained with hematoxylin and eosin by standard techniques.

\section{Results}

Digestion of KS on PG enhances APC-mediated T hybridoma reactivity. The reactivities of two T cell hybridomas, TH5 and TH14, were studied before and after treatment of PG with two different glycosidases. Treatment of PG with chondroitin ABC lyase, which removes the CS chains and leaves only residual pentasaccharides on the core protein (14), had no effect on the reactivities of either $\mathrm{T}$ cell hybridoma (Fig. 1). However, the treatment of PG with keratanase, which cleaves KS chains attached to the core protein of PG (26), increased the reactivity 


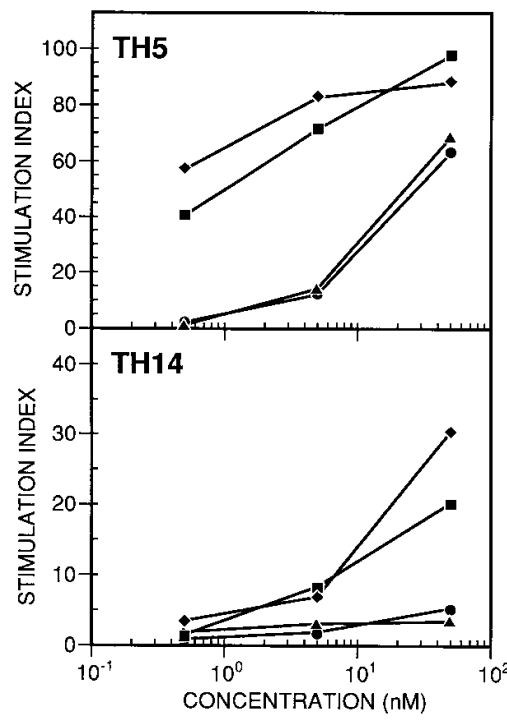

Figure 1. Reactivities of the $\mathrm{T}$ cell hybridomas TH5 and TH14 to aggrecan with or without glycosidase treatments. Native human fetal PG (filled circles); $\mathrm{ABC}$ chondroitinasedigested human fetal PG (filled triangles); keratanase-digested human fetal PG (filled squares); and a combination of chondroitinase- and keratanasedigested human fetal PG (filled diamonds) were added at various concentrations (molar protein). Supernatants were harvested $24 \mathrm{~h}$

later and tested for IL-2 in CTLL proliferation assays as described in text. All digestions were performed in the presence of protease inhibitors.

of both hybridomas when compared with the untreated PG or the CS-depleted PG (Fig. 1). The reactivity of TH5 cells was significantly higher with KS-depleted PG as compared with native $\mathrm{PG}$ at three different doses $(0.5,5$, and $50 \mathrm{nM}$, respectively). Similar results were obtained at higher concentrations for the reactivity of TH14. Digestion with chondroitin ABC lyase either before (Fig. 1) or after (data not shown) keratanase digestion did not further increase the responses of either TH5 or TH14. Similar results were obtained in at least two other separate experiments.

A

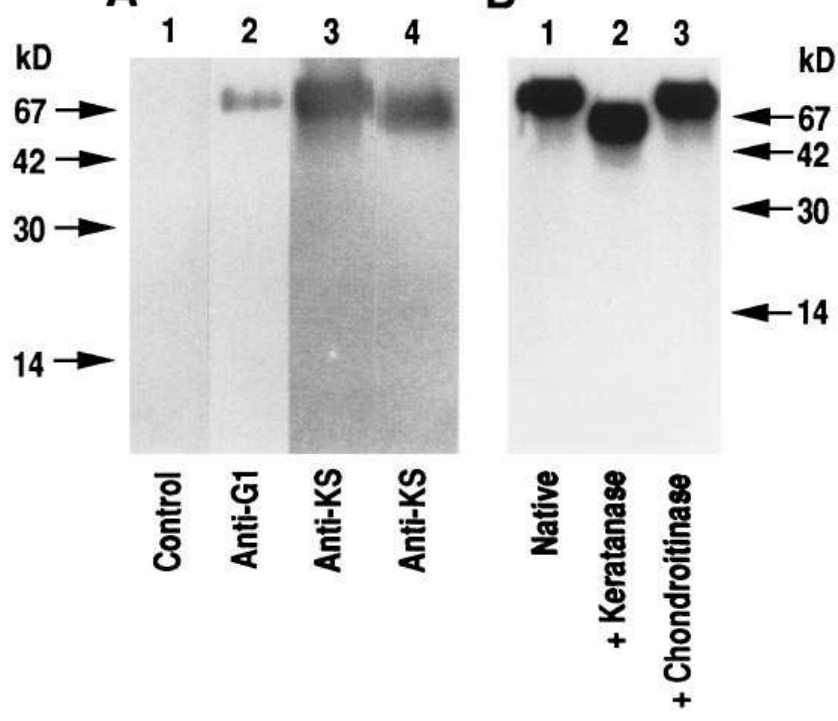

Figure 2. Demonstration of KS on G1. (A) Immunoblotting of native G1 (lanes 1-3) with control mouse immunoglobulin (SP2/0), anti-G1 $\mathrm{mAb}$ (1C6), and anti-KS mAb (AN9P1) as ascitic fluids and of G1 digested with keratanase and immunoblotted with anti-KS $\mathrm{mAb}$ (AN9P1) (lane 4). (B) Autoradiography of ${ }^{125} \mathrm{I}-\mathrm{G} 1$ (10,000 cpm/lane) run on $12.5 \%$ SDS-PAGE before and after glycosidase digestions (lanes 1-3).
Presence of KS on purified bovine G1 preparation. Since these $\mathrm{T}$ hybridomas both react with the $\mathrm{G} 1$ globular domain of aggrecan (9), we examined G1 for the presence of KS and CS. Native G1, keratanase-digested G1, and chondroitin ABC lyase-digested G1 were electrophoresed on a $12.5 \%$ polyacrylamide gel and transferred onto a PVDF membrane. Each membrane was stained with one of the following: Alcian blue which stains negatively charged GAG chains; or immunoblotted with an anti-G1 and G2 mAb (1C6), or with one of two anti-KS antibodies (AN9P1 and 5D4). The anti-KS antibodies AN9P1 (Fig. $2 A$ ) and 5D4 (not shown) bound to undigested G1, showing the presence of immunoreactive KS in the purified G1 preparation. Alcian blue stained native G1, but not keratanase-digested G1, on a $12.5 \%$ SDS-PAGE gel (not shown). Staining with 1C6, and use of radiolabeled G1 showed that the native form of G1 migrated as a single band with an apparent molecular mass of $71 \mathrm{kD}$ (Fig. 2, $A$ and $B$ ), but keratanase-digested G1 migrated with increased mobility with an apparent molecular mass of $64 \mathrm{kD}$ (Fig. 2 B). It still reacted with antibody to $\mathrm{KS}$, indicating that the digestion was incomplete or that the residual KS resists digestion. Chondroitin ABC lyase treatment of G1 did not change the molecular mass of the molecule (Fig. $2 \mathrm{~B}$ ), indicating the absence of CS.

Digestion of $K S$ on $G 1$ enhances APC-mediated $T$ cell reactivity. The responsiveness of TH5 to keratanase-digested G1 was significantly increased at 0.5 and $5 \mathrm{nM}$ of antigen, but was similar to native $\mathrm{G} 1$ at $50 \mathrm{nM}$ (Fig. 3). The responsiveness of TH14 to G1 was less sensitive to digestion with keratanase, but a significant increase of reactivity after KS depletion was observed at $50 \mathrm{nM}$ (Fig. 3). Similar data were obtained on two other separate occasions, whether or not spleen cells used as APC were irradiated before use (data not shown).

Absence of demonstrable protease activity in keratanase preparation. One explanation for the increased $\mathrm{T}$ cell reactivity after keratanase digestion of the antigen could be the release of immunoreactive peptides by cleavage of the antigen by proteases contaminating the keratanase preparation. However, under the conditions of use it had no detectable proteolytic activity in the sensitive casein degradation assay (data not shown). In addition, no degradation of ${ }^{125} \mathrm{I}-\mathrm{G} 1$ was seen after keratanase digestion as evidenced by the lack of release of

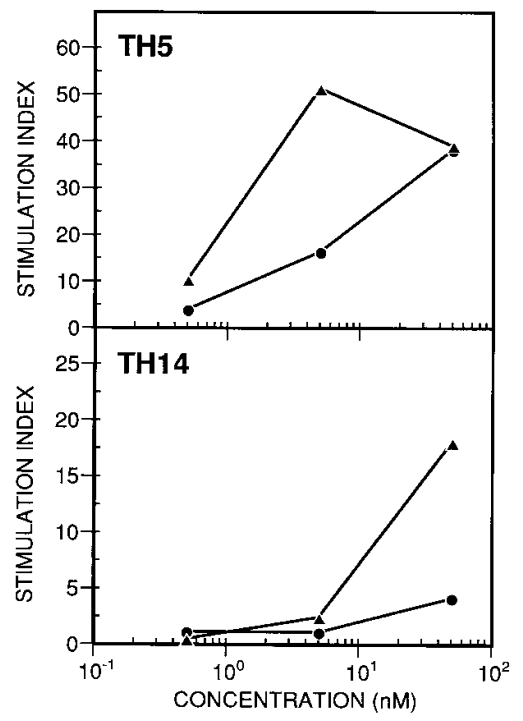

Figure 3. Reactivities of the T cell hybridomas TH5 and TH14 to G1 with or without keratanase treatment. Native G1 (filled circles) and keratanasedigested G1 (filled triangles) were used in assays as in Fig. 1. 
Table I. CNBr-digested G1, but Not Keratanase-digested G1, Can Be Presented by Fixed APC

\begin{tabular}{lccccc}
\hline & \multicolumn{2}{c}{ Nonfixed APC } & & \multicolumn{2}{c}{ Fixed APC } \\
\cline { 2 - 3 } \cline { 5 - 6 } \multicolumn{1}{c}{ Antigen } & TH5 & TH14 & & TH5 & TH14 \\
\hline Medium & $429 \pm 133$ & $310 \pm 200$ & & $854 \pm 345$ & $674 \pm 430$ \\
G1 native & $7020 \pm 532$ & $1413 \pm 350$ & & $755 \pm 648$ & $510 \pm 237$ \\
G1 KS-depleted & $21987 \pm 1400$ & $6361 \pm 800$ & & $208 \pm 6$ & $399 \pm 313$ \\
$\begin{array}{l}\text { G1 CNBr- } \\
\quad \text { digested }\end{array}$ & $30034 \pm 1060$ & $8615 \pm 824$ & & $20508 \pm 1277$ & $10718 \pm 1700$ \\
& & & & & \\
& & & & &
\end{tabular}

Results expressed as cpm (mean \pm SEM) of CTLL-2 proliferation assays as in text. BALB/c spleen cells were used as APC either without fixation or after fixation with $1 \%$ formaldehyde. Antigen was $\mathrm{G} 1$ in the native form or after digestion with keratanase or $\mathrm{CNBr}$. The concentrations of G1 used were $5 \mathrm{nM}$ for TH5 and $50 \mathrm{nM}$ for TH14.

${ }^{125}$ I-containing fragments and by the absence of proteolytic fragments on autoradiography.

Furthermore, if the enhanced reactivity was due to release of the immunoreactive peptide in vitro, the peptide may have been presented to the T cells by MHC class II molecules on the surface of fixed APC (27). However, as shown in Table I, KS-depleted G1 could not be presented by fixed APC to the $\mathrm{T}$ cells.

Reduction and alkylation of G1 enhances APC-mediated $T$ cell reactivity. Reduction and alkylation of $\mathrm{G} 1$ to produce denaturation by removal of intramolecular disulfide bonds enhanced $\mathrm{T}$ cell responses. Thus, reactivity of the TH5 hybridoma at the suboptimal concentration of $5 \mathrm{nM}$ was increased from an SI of $36 \pm 5.7$ for native G1 to $98 \pm 8$ after reduction and alkylation. In comparison, removal of KS alone by keratanase produced an even greater response with an SI of $153 \pm 9$ or $156 \pm 22$ if keratanase treatment followed reduction and alkylation. Thus, denaturation of G1 enhances the T cell response, but removal of KS enhances the response even further to that observed by removal of KS only.

$\mathrm{CNBr}$ digestion of $\mathrm{G1}$ enhances $A P C$-mediated $T$ cell reactivity and identifies locations of $T$ cell epitopes. Treatment of G1 with CNBr produced multiple peptides of 24, 19, 15, and 14 kD detected with Aurodye staining after SDS-PAGE (Fig. 4).
TH5 responded to the $19-\mathrm{kD}$ CNBr fragment blotted onto a PVDF membrane (Fig. 4). The amino-terminal sequence of this fragment was HGIED. Therefore, the epitope is located between residues 118 and 232 (Fig. 5) in the B region of the tandem repeat (Fig. 6) of the bovine G1 sequence which has been described elsewhere (28, 29, and Rosenberg, L., and P. Neame, unpublished data). This fragment contains no KS attachment sites. These have been shown to reside in the interglobular domain of pig laryngeal cartilage and may be present at residues 352 and 357 in the bovine sequence (Figs. 5 and 6). TH14 recognized the $15-\mathrm{kD}$ CNBr peptide (Fig. 4) with the amino-terminal sequence HPVTT starting at residue 41 and ending at residue 104 (Fig. 5). This is located in the Ig fold of G1 (Fig. 6). TH14 also showed reactivity, to a lesser extent, with the 19-kD CNBr peptide (HGIED....) which exhibits some homology at its amino-terminal end with a sequence at the carboxy-terminal end of the $15-\mathrm{kD} \mathrm{CNBr}$ peptide namely SD/QATLE (Fig. 5).

The exact sequences of the TH5 and TH14 epitopes are now being characterized. Neither of these CNBr peptides of 19 and $15 \mathrm{kD}$ contained detectable $\mathrm{KS}$ by immunoblotting of $\mathrm{CNBr}$-digested G1 with anti-KS mAb (Fig. 4). In addition, keratanase treatment of CNBr-digested G1 did not alter the mobility of the 19- and 15-kD peptides on SDS-PAGE (data not shown).

Cleavage of $\mathrm{G} 1$ by $\mathrm{CNBr}$ also led to an increased responsiveness of both TH5 and TH14 to G1 compared with native or keratanase-digested G1 presented by viable APC (Table I). Keratanase digestion of CNBr-treated G1 did not further enhance the reactivity over that to $\mathrm{CNBr}$-treated $\mathrm{G} 1$ alone (data not shown). This was anticipated since $\mathrm{KS}$ is not present in the $\mathrm{CNBr}$ peptides recognized by TH5 and TH14 as shown above. Moreover, both the $\mathrm{CNBr}$ peptides were presented by fixed APC to the T cells (Table I) indicating that removal of KS by cleavage of core protein led to recognition and binding of peptides by these $\mathrm{T}$ cell hybridomas without digestion mediated by APC. Further cleavage of antigen cannot be ruled out since this could be mediated either extracellularly or intracellularly by the $\mathrm{T}$ cell hybridomas.

Uptake of radiolabeled G1 domain by APC is enhanced by removal of $K S$ from the interglobular domain: degradation is unaffected. Rapid enhanced cellular binding and/or uptake
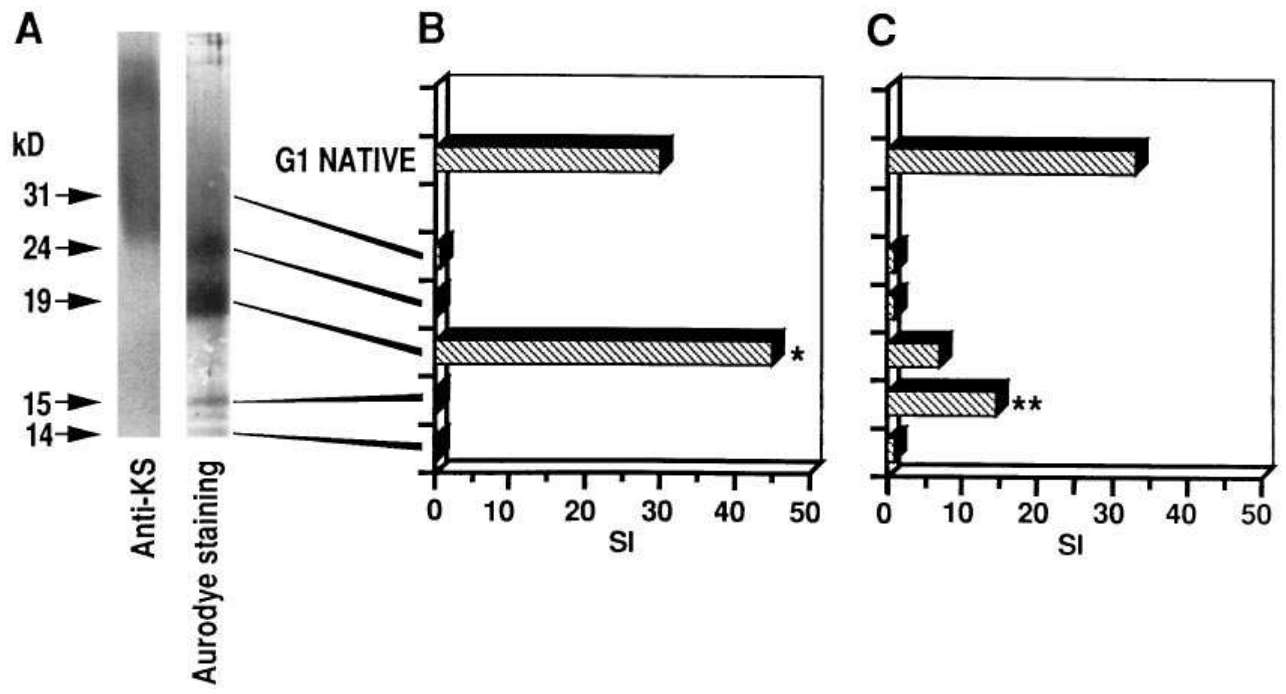

Figure 4. Localization of TH5 and TH14 epitopes on $\mathrm{CNBr}$ peptides of G1. CNBr-digested G1 was run on $12.5 \%$ SDS-PAGE and transferred onto PVDF. $(A)$ Aurodye staining. (B) Reactivity of TH5 to individual fragments. (C) Reactivity of TH14 in response to individual $\mathrm{CNBr}$ fragments. Amino-terminal sequences of the $\mathrm{G} 1 \mathrm{CNBr}$ fragments are HGIED for the TH5 reactive peptide $(*)$ and EGEVF for the TH14 reactive peptide $(* *)$. 


\section{BOVINE G1}

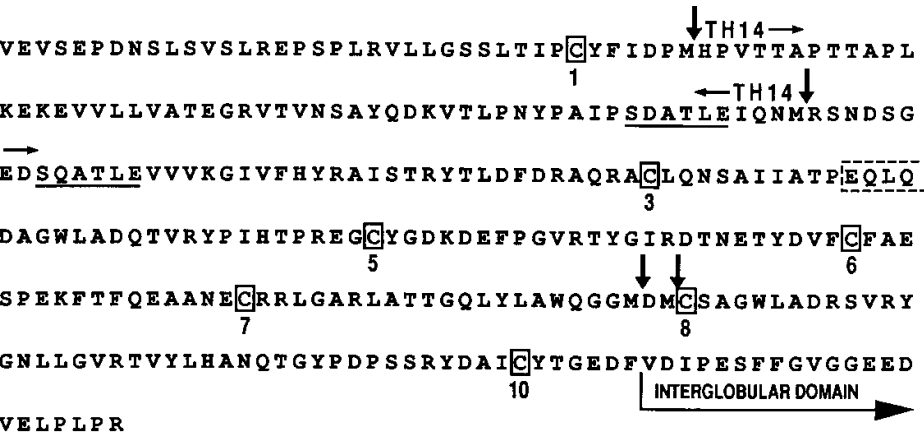

Figure 5. Bovine G1 sequence showing locations of the TH5 and 52 TH14 cyanogen bromide peptides. This is based on references 11028,29 , and Neame, P.J., and L.C. Rosenberg, unpublished data.

170 Black arrows are CNBr cleavage sites. $\mathrm{CNBr}$ peptides recognized by TH5 (19 kD) and TH14 (15 $\mathrm{kD})$ are indicated. Putative KS attachment sites (shaded boxes) are based on the porcine G1 sequence (reference 11). The locations of the I-C-6 epitope sequence are also indicated (open

boxes) (reference 31). The cysteines are boxed and numbered from the amino terminus to permit comparison to Fig. 6. Sequence homologies in the TH5 and TH14 peptides are underlined.

was observed (time 0) after addition of radiolabeled G1 after removal of KS (Fig. $7 a$ ). In a representative experiment this was observed both in the absence (Fig. $7 a$ ) and the presence (Fig. $7 c$ ) of $\mathrm{NaN}_{3}$ used to inhibit endocytosis. Thus this increased uptake is due mainly to cell surface binding. On subsequent incubation at $37^{\circ} \mathrm{C}$, this enhanced binding $\left( \pm \mathrm{NaN}_{3}\right)$ without KS was maintained (Fig. 7, $a$ and $c$ ), reaching a maximum by $\sim 15 \mathrm{~min}$ and reducing thereafter up to $60 \mathrm{~min}$.

The net difference in binding and rate of uptake subsequently remained essentially unchanged up to $480 \mathrm{~min}$. When $\mathrm{NaN}_{3}$ was present to permit cellular binding and yet prevent sodium azide-sensitive endocytosis, binding was increased for $\mathrm{G} 1+\mathrm{KS}$ and more so for $\mathrm{G} 1-\mathrm{KS}$ up to $15 \mathrm{~min}$ and did not markedly increase thereafter (Fig. $7 \mathrm{c}$ ). However, binding of G1 was always enhanced after removal of KS. Thereafter the differences in the amount bound remained constant. When uptake/binding of G1 lacking $\mathrm{KS}(-\mathrm{KS})$ was examined in the presence and absence of $\mathrm{NaN}_{3}$, we noted in separate experiments a reproducible transient peak of enhanced uptake in the absence of $\mathrm{NaN}_{3}$ at 15 min which was never observed in the presence of $\mathrm{NaN}_{3}$ (Fig. 7 b). This would appear to represent a transient enhanced endocytosis (inhibitable by $\mathrm{NaN}_{3}$ ) over and above the enhanced cell surface binding shown in Fig. $7 c$ (seen with $\mathrm{NaN}_{3}$ ). Subsequently, a steady state is reached. When KS remained on G1 there was no significant change in uptake in the presence of $\mathrm{NaN}_{3}$ (Fig. $7 d$ ). Thus, removal of KS from G1 resulted in increased binding to APC which accounted for the increased uptake seen in the absence of $\mathrm{NaN}_{3}$ (Fig. 7 b).

When binding to the APC surface in the absence of $\mathrm{NaN}_{3}$ was examined by treating cells with trypsin to remove cell surface-bound G1 we found that at $30 \mathrm{~min} \sim 65-75 \%$ of G1-KS was removed with trypsin. This did not change significantly with time. This value compared very well with the experiment shown in Fig. 7, $a-d$, where we showed that at $30 \mathrm{~min} \sim 65-$ $75 \%$ of the G1 lacking KS bound in the presence of $\mathrm{NaN}_{3}$ compared with that noted in its absence. In this case, the proportion of $\mathrm{NaN}_{3}$-inhibitable binding of the total increased with time. Thus, these experiments clearly show that removal of KS leads to enhanced APC association of G1 and that this involves primarily cell surface binding which results in enhanced endocytosis. These results were reproduced in a subsequent repeat experiment.

We also examined loss of G1 from APC to see if this is influenced by KS. When cells were incubated with radiolabeled $\mathrm{G} 1 \pm \mathrm{KS}$ for $30 \mathrm{~min}$ at $37^{\circ} \mathrm{C}$, washed, and incubated in the absence of further G1 to determine loss/digestion of G1, we ob-

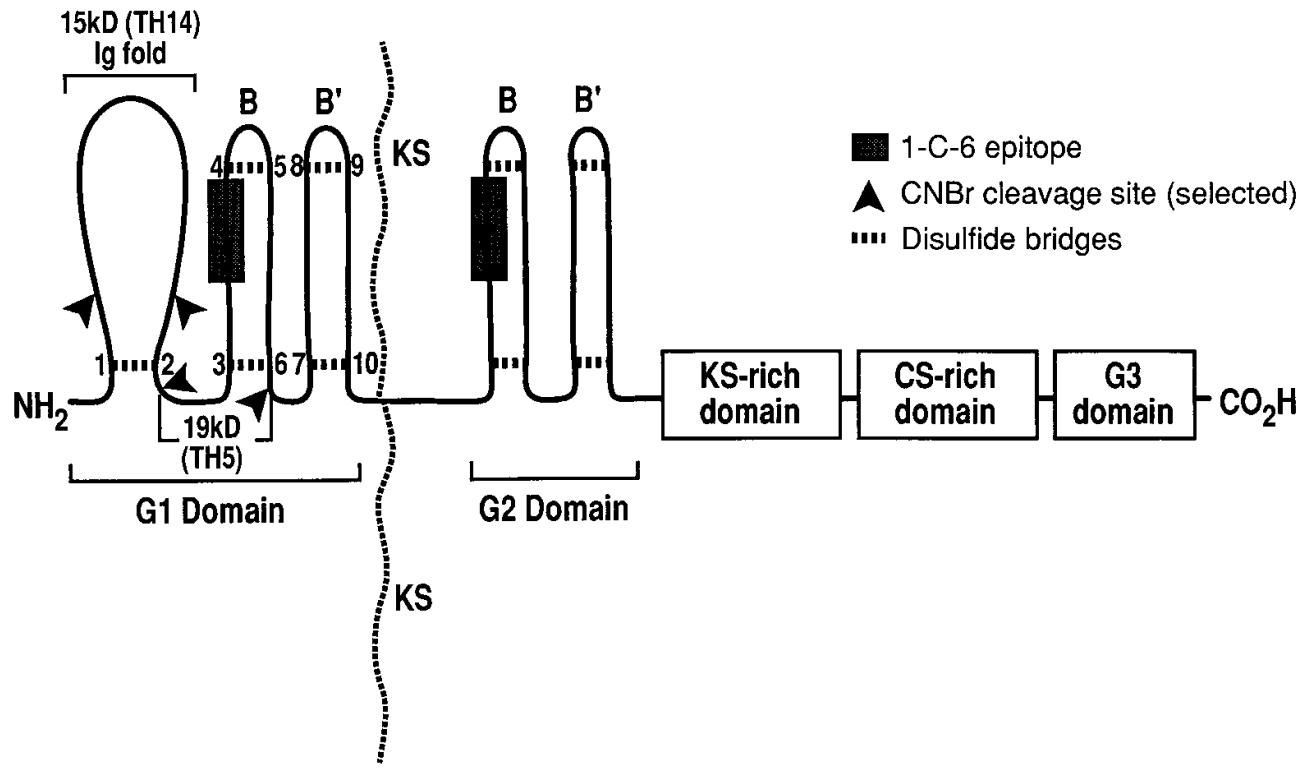

Figure 6. Diagrammatic representation of the G1 globular domain. This demonstrates the locations of $\mathrm{CNBr}$ peptides containing the TH5 $(19 \mathrm{kD})$ and TH14 $(15 \mathrm{kD})$ epitopes and the location of the 1-C-6 epitope and some of the KS attachment sites in the interglobular domain (modified from reference 31$)$. 


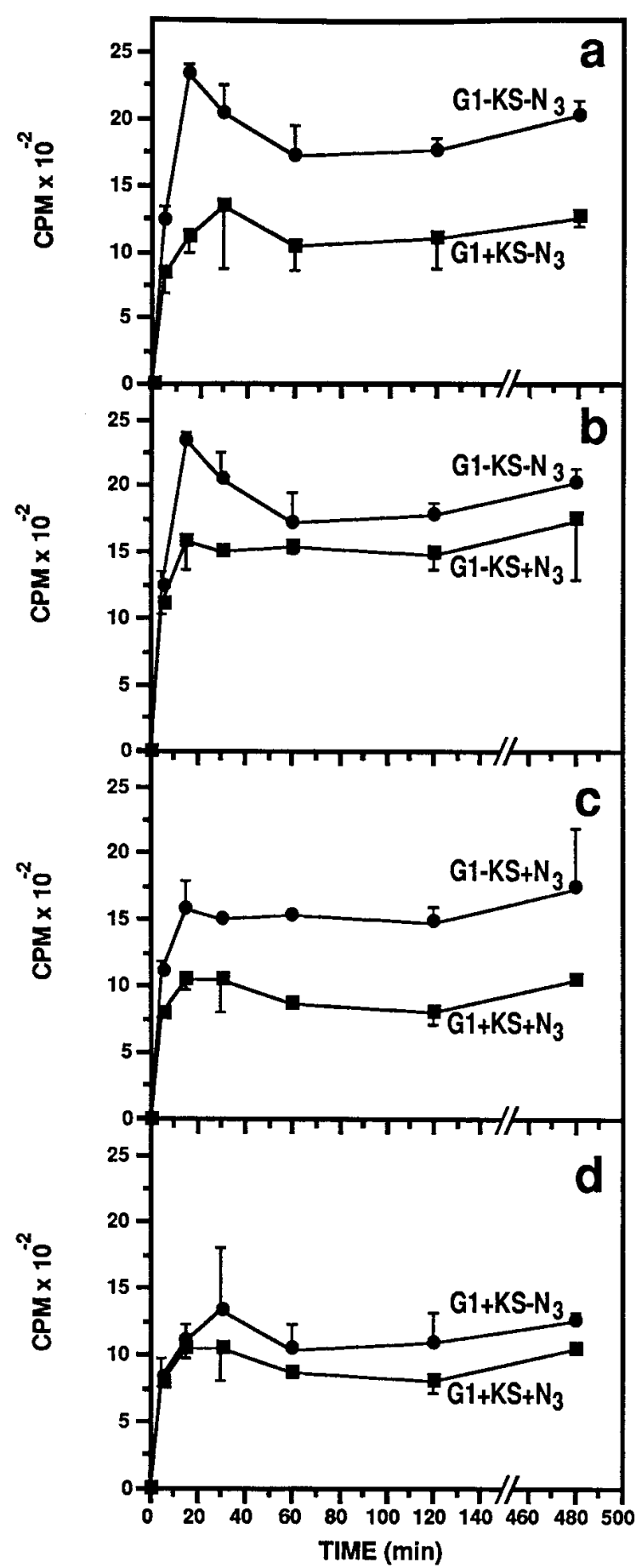

Figure 7. Influence of KS on uptake of G1 by APC. Uptake of ${ }^{125}$ I-G1 by nonirradiated spleen APC determined with (-) and without $(+)$ removal of KS mainly involves binding to the cell surface. Cells were cultured with $(+)$ or without $(-) \mathrm{NaN}_{3}\left(N_{3}\right)$. Comparisons are made for uptake of $(a) \mathrm{G} 1 \pm \mathrm{KS}-\mathrm{N}_{3},(b) \mathrm{G} 1-\mathrm{KS} \pm \mathrm{N}_{3},(c)$ $\mathrm{G} 1 \pm \mathrm{KS}+\mathrm{N}_{3}$, and $(d) \mathrm{G} 1+\mathrm{KS} \pm \mathrm{N}_{3}$. Experimental points represent the means of duplicate determinations. Error bars are shown.

served that ${ }^{125} \mathrm{I}-\mathrm{G} 1$ was progressively lost from the cell and that the rate of loss of G1 (loss of TCA-precipitable undigested G1 from cells) was similar in the presence and absence of KS (Fig. 8 ). Counts of TCA-insoluble ${ }^{125} \mathrm{I}-\mathrm{G} 1 \pm \mathrm{KS}$ were reduced by $\sim 50 \%$ within $30 \mathrm{~min}$ and much more slowly thereafter. Rela-

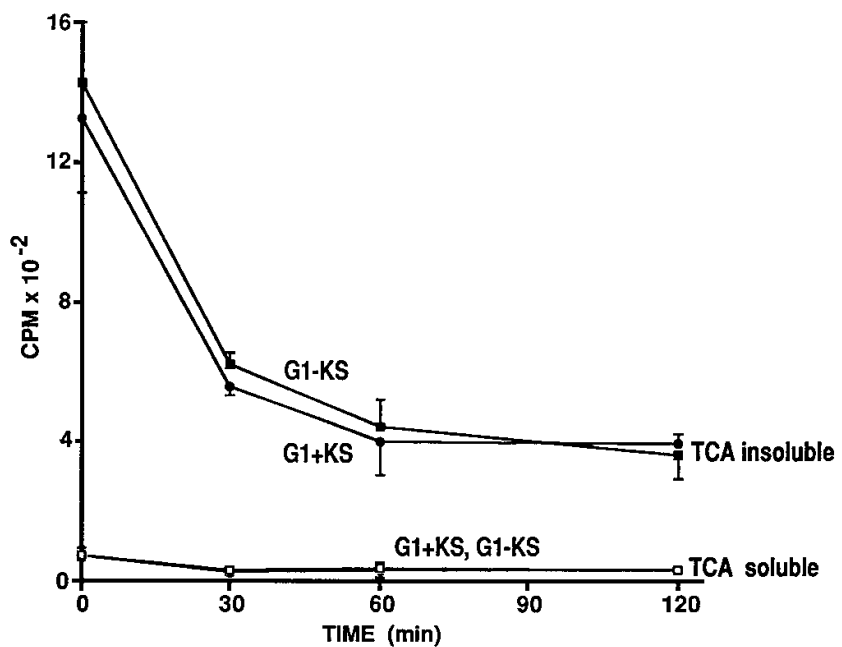

Figure 8. Rate of loss of ${ }^{125} \mathrm{I}-\mathrm{G} 1$ bound to and endocytosed by APC. Radiolabeled G1 \pm KS was bound to APC for 30 min and cells were washed to remove unbound $\mathrm{G} 1 \pm \mathrm{KS}$. They were incubated at $37^{\circ} \mathrm{C}$ and the TCA insoluble and soluble G1 were determined with time. Experimental points represent the means of duplicate determinations. Error bars are shown.

tively few counts were present in the TCA-soluble (digested) form regardless of time. Thus, the presence of KS had no detectable effect on digestion of G1 in these APC.

Induction of arthritis: clinical characterization. Mice received a maximum of five injections of each antigen. However, when arthritis appeared and persisted in a mouse, injections of that animal ceased. Injection of native (non-glycosidase-treated) bovine G1 globular domain bearing KS chains produced arthritis in only one animal (Table II and Fig. 9). When CS or KS was removed from bovine $\mathrm{PG}$, arthritis was only detected in 1-2 of 20 mice and mean disease severity was low. Moreover, onset was late (mean of day 107). This lack of ability of bovine PG to induce arthritis confirms our earlier studies (3). However, removal of both KS and CS from PG increased the incidence of arthritis for PG to 5 of 20. Yet the mean severity (2.9) was low. But when KS was removed by keratanase from G1 $(\mathrm{G} 1-\mathrm{KS})$ and it was injected at a lower molar concentration

Table II. Induction of Arthritis in BALB/c Mice: Comparison of Bovine G1 Globular Domain with Bovine PG

\begin{tabular}{lrrr}
\hline \multicolumn{1}{c}{ Antigen ( $\mu$ g protein per injection) } & $\begin{array}{c}\text { Mean day } \\
\text { of onset }\end{array}$ & & \\
\hline G1 native (25) & 76 & 7.0 & $1 / 23$ \\
G1-KS removed (25) & 67 & 11.7 & $14 / 21$ \\
Bovine PG (100) & 0 & 0 & $0 / 20$ \\
Bovine PG (100) CS removed & 107 & 2.0 & $2 / 20$ \\
Bovine PG (100) KS removed & 84 & 6.0 & $1 / 20$ \\
Bovine PG (100) CS + KS removed & 86 & 2.9 & $6 / 20$ \\
$\begin{array}{l}\text { Bovine PG (100) CS removed plus } \\
\quad \text { G1 - KS removed (25) }\end{array}$ & 66 & 12.9 & $14 / 20$ \\
Bovine PG (100) CS removed & & & \\
$\quad$ plus G1 native (25) & 0 & 0 & $0 / 9$ \\
& & & \\
\hline
\end{tabular}

Maximum total injections was five. Injections ceased when arthritis first appeared. G1 was prepared from calf articular cartilage and bovine PG was from adult nasal cartilage. 


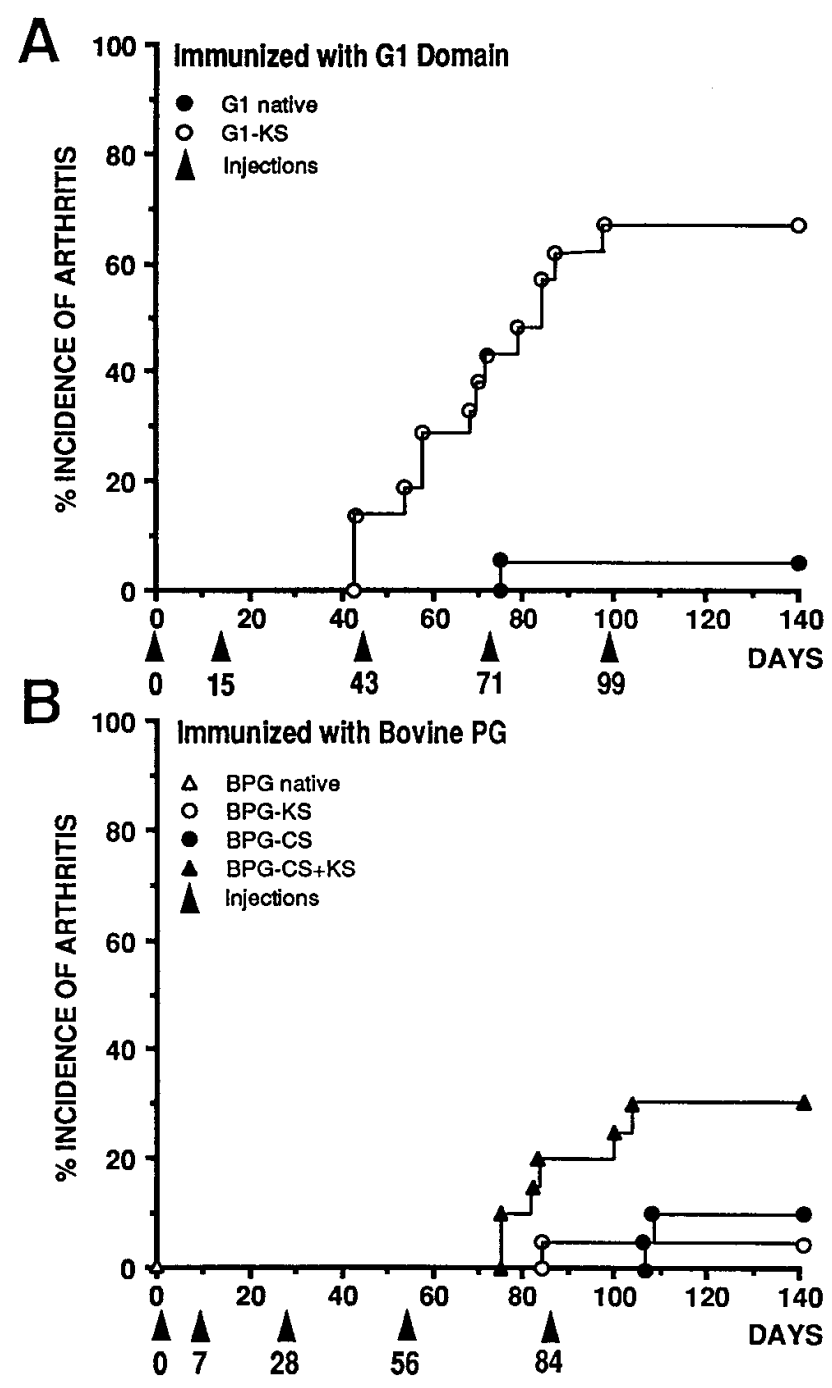

Figure 9. Induction of arthritis in mice injected with the $\mathrm{G} 1$ globular domain. Injections, incidence, and onset of arthritis in mice injected with native $\mathrm{G} 1, \mathrm{G} 1$ treated with keratanase $(\mathrm{G} 1-\mathrm{KS})(A)$, bovine PG both native $(B P G)$ and keratanase-treated $(B P G-K S)$, chondroitinase $\mathrm{ABC}-$ treated $(B P G-C S)$, and treated with both glycosidases $(B P G-C S+K S)(B)$.

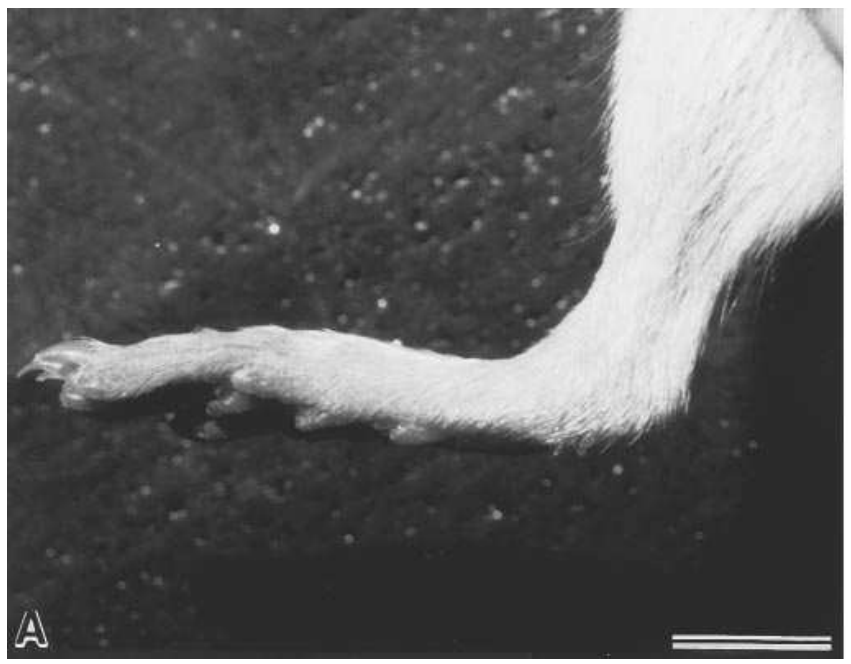

than PG, 14 of 21 mice developed an arthritis of high severity and earlier onset (Table II and Fig. 9). It was first noted after only two injections (Fig. 9). This contrasted strikingly with the lack of arthritis induced by native G1. Arthritis was characterized by early swelling of front and/or hind paws (Fig. 10). No specific pattern was noted.

The combination of CS-depleted PG with native G1 was examined to determine whether epitopes on the core protein of bovine PG other than those on G1 could contribute to arthritis development. This produced no arthritis, but when this CS-depleted PG was mixed with G1 lacking KS, the incidence, onset, and severity of arthritis was very similar to that seen with KS-depleted G1 alone (Table II). PG lacking CS and KS injected with G1 was not studied. These results point to only a role for $\mathrm{G} 1$ in arthritis induction.

These observations clearly demonstrate the capacity of the G1 globular domain of PG to induce arthritis but only after removal of KS. Thus, KS can markedly inhibit arthritis induction and this is also seen in the case of intact PG where an inhibitory effect for CS is also seen in fetal human molecules lacking KS (3). The arthritis that developed with these antigens was severe for G1 and moderate for PG (Table II). It was chronic and persisted from the time of its first appearance for a period of up to $100 \mathrm{~d}$ when the animals were killed (to meet the requirements of the local animal care committee).

Histology. Histological examination of swollen joints 8-17 wk from onset confirmed the presence of an active erosive inflammatory arthritis. Swollen front (Fig. 11) paws and knees (Fig. 11, $B$ and $C$ ) contained an abundance of mononuclear cell and polymorphonuclear leukocyte infiltration both in and around joints. Erosive destruction of cartilage and bone was commonly observed in both front and rear paws and in knees (Fig. 11, $B-D$ ). In the latter case the presence of a strong synovitis with formation of pannus over degenerating cartilage was noted. Knee joints often contained polymorphonuclear leukocytes in joint cavities although they are not so apparent in Fig. $11 B$.

Spondylitis was also observed as a mononuclear cell infiltration around the intervertebral discs in the base of the tail (Fig. 12, $B$ and $C$ ). This was observed at the time of the polyarthritis. It started immediately adjacent to the annulus (Fig. $12 \mathrm{~B}$ ), was usually bilateral, and was characterized by a strong

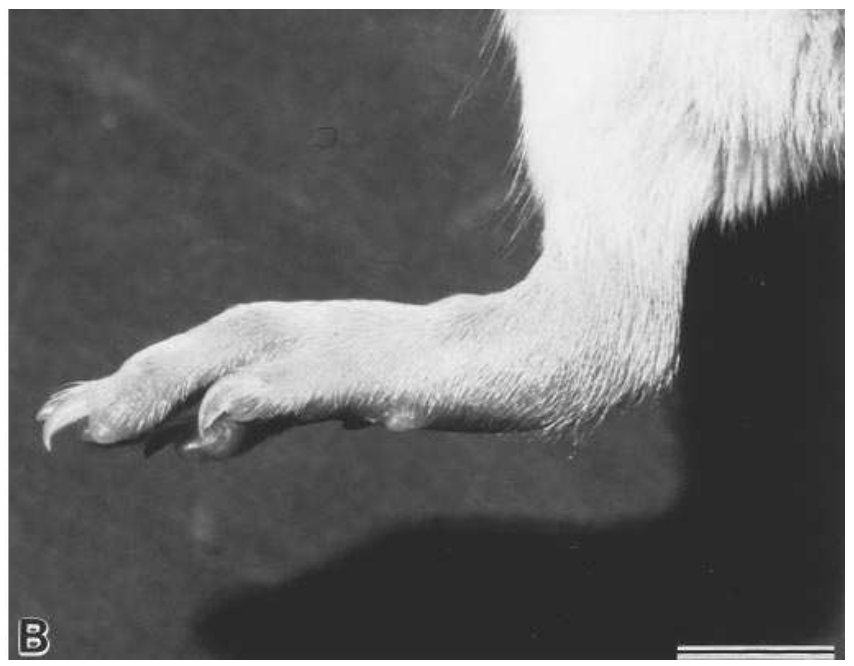

Figure 10. Photographs to show development of arthritis by G1 globular domain. (A) Normal and (B) swollen arthritic hind paws $18 \mathrm{~d}$ after appearance of arthritis after injection of G1 depleted of KS. Bar, $4 \mathrm{~mm}$. 

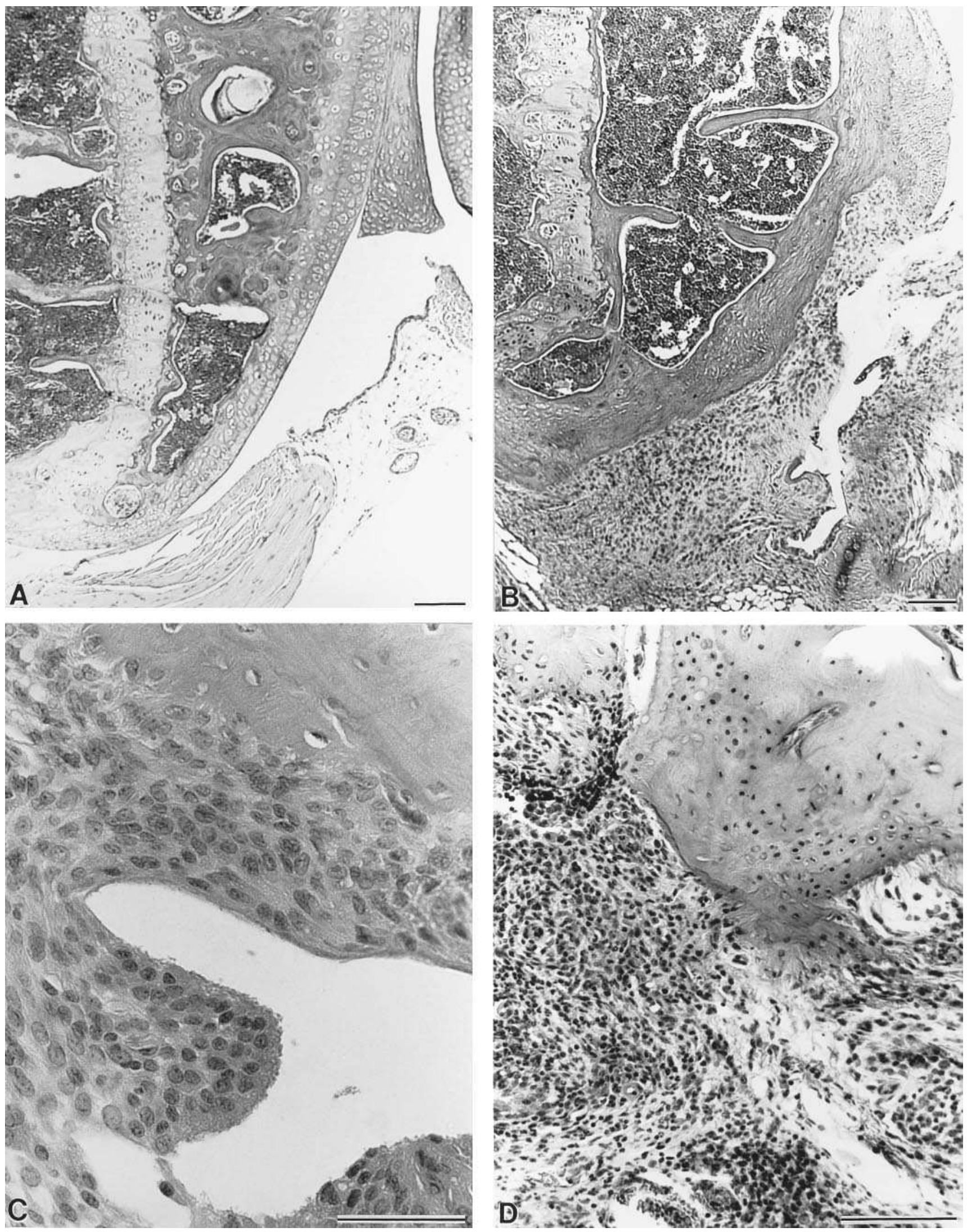

Figure 11. Histology of arthritis in the appendicular skeleton. 6- $\mu \mathrm{m}$ sections were stained with hematoxylin and eosin and show $(A)$ normal knee, $(B$ and $C)$ arthritic knee, and $(D)$ arthritic front paw after injection of G1 depleted of KS. The strong synovitis in $B 55 \mathrm{~d}$ after onset includes pannus formation and loss of cartilage from the tibial plateau. A higher power view of the cellular pannus tissue is shown in $C 20 \mathrm{~d}$ after onset. The intense mononuclear cell infiltration in $D$ is at $115 \mathrm{~d}$ after onset. Bars, $A, B$, and $D, 100 \mu \mathrm{m} ; C, 50 \mu \mathrm{m}$. 

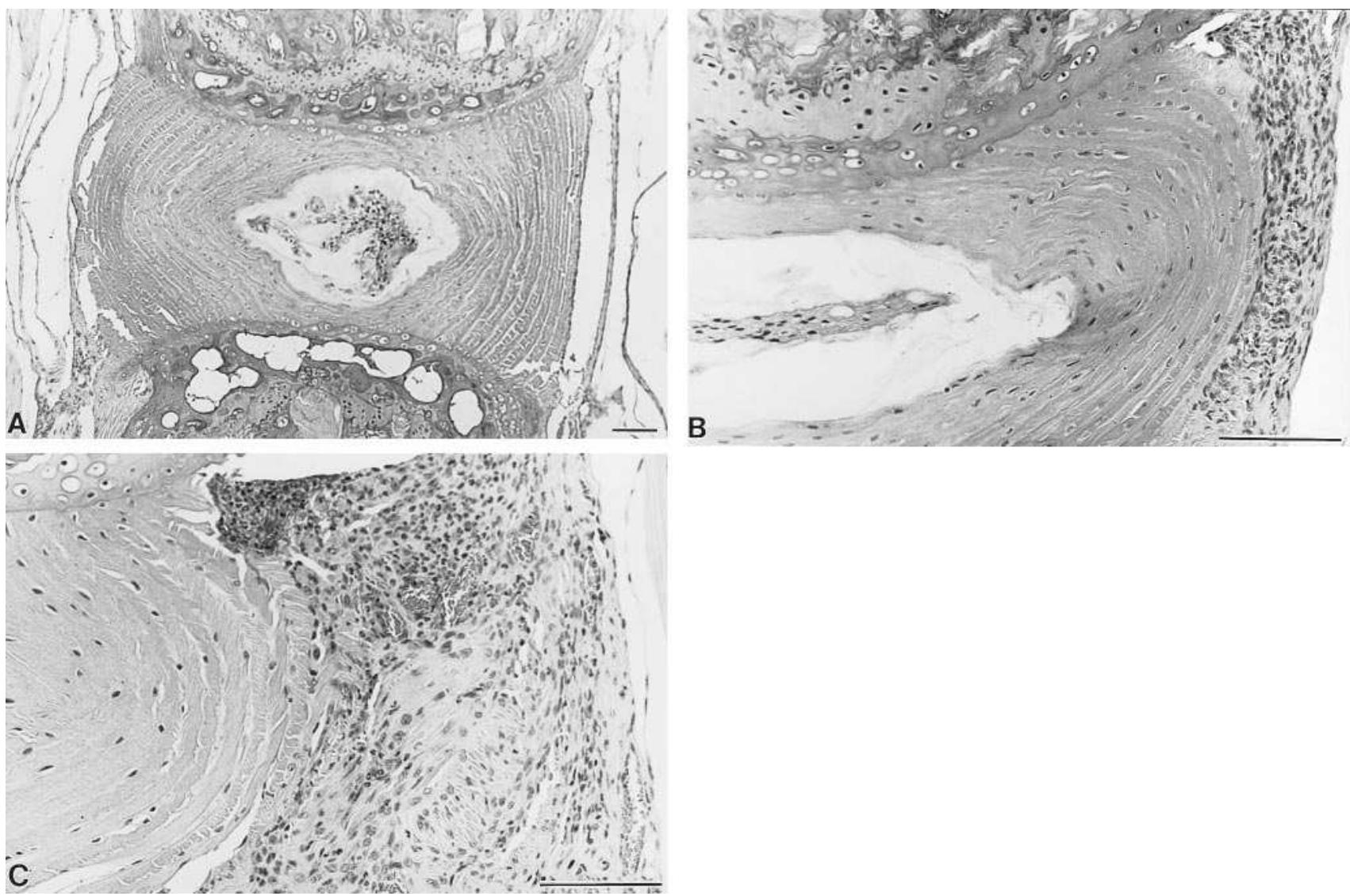

Figure 12. Histology of spondylitis in the axial skeleton. 6- $\mu \mathrm{m}$ sections were stained with hematoxylin and eosin and show $(A)$ normal intervertebral disc at the base of the tail showing the central nucleus and the surrounding annulus and the cartilaginous endplates. In $B$ and $C$ are shown intervertebral discs of mice injected with G1 depleted of KS to show, at $120 \mathrm{~d}$ after onset of arthritis, $(B)$ the early mononuclear cell infiltration adjacent to the annulus and $(C)$ a more advanced pathology in the same site. Bars, $100 \mu \mathrm{m}$.

cellular infiltration of adjacent tissue (Fig. 12, $B$ and $C$ ). Unlike in diarthrodial joints, polymorphs were usually absent.

\section{Discussion}

Our earlier studies linking cellular immunity to aggrecan, the major proteoglycan of cartilage, with the development of arthritis in $\mathrm{BALB} / \mathrm{c}$ mice $(3,4,6)$ raised the important question of the location of the arthritogenic epitope(s) responsible for induction of this experimental disease. The present study demonstrates that the isolated G1 globular domain of the bovine molecule, when depleted of KS, can potently induce arthritis of high severity and chronicity which includes a spondylitis of the kind previously observed with human fetal PG. That the arthritogenic epitope(s) responsible for this arthritis is located in the G1 domain is further indicated by the lack of enhancement when PG depleted of CS chains was included in the immunization with G1 depleted of KS.

The work that lead to the identification of the G1 globular domain resulted from careful analyses of in vitro responses of two T cell hybridomas TH5 and TH14 which recognize distinct epitopes on both human fetal and adult PG (9) and use different $\mathrm{T}$ cell receptors (9). These epitopes are clearly present on the G1 globular domain and KS is also bound to core protein associated with this domain. The presence of KS can also diminish in vitro responsiveness of these cells to the G1 globular domain and the intact PG molecule. Denaturation of G1 by re- duction and alkylation or partial removal of KS by digestion of PG or G1 with keratanase or complete removal of KS by $\mathrm{CNBr}$ cleavage of the core protein of the $\mathrm{G} 1$ preparation can each enhance reactivity of these T cells to both PG and G1 in vitro. The consequence of this is reflected in vivo by the induction of arthritis by G1 after KS is removed by keratanase. Since, on a molar basis, these in vitro effects of keratanase are similar (compare Figs. 1 and 3), it is likely that the KS chains present in association with the Gl domain primarily account for these inhibitory effects on $\mathrm{T}$ cell recognition and identify the inhibitory effect of KS on induction of arthritis observed in KS-rich adult PG molecules (3).

Whereas calf G1 globular domain (carboxy terminus defined by the last cysteine residue, see Fig. 5) may or may not contain KS, the G1-G2 interglobular domain of porcine aggrecan can contain up to two O-linked KS chains on threonine residues at positions 352 and 357 (11). Similarly the G1-G2 interglobular domain of calf aggrecan may also bear KS chains (Figs. 5 and 6). These would be located on $\mathrm{CNBr}$ fragments other than those recognized by TH5 and TH14 explaining the enhanced responsiveness after $\mathrm{CNBr}$ cleavage. Moreover, the gel electrophoretic mobilities of the $\mathrm{CNBr}$ peptides recognized by TH5 and TH14 did not change after keratanase treatment, and they did not stain with the two anti-KS antibodies.

Keratan sulfate on G1 or PG could theoretically inhibit antigen presentation by APC at the levels of binding and endocytosis, intracellular compartmentalization (receptor mediated 
or not), enzymatic digestion in endosomal compartments in $\operatorname{APC}(27,30)$ and/or binding to MHC class II molecules, and presentation to $T$ cells. Our studies of G1 uptake reveal that partial removal of KS by digestion of this GAG clearly enhances binding to the APC cell surface (shown by trypsin removal of cell surface-bound material and by uptake in the presence of $\mathrm{NaN}_{3}$ to block endocytosis). Endocytosis is also transiently enhanced when KS is removed. However, the rate of digestion of G1 by APC is unaffected by the presence of KS. Thus, the enhanced $\mathrm{T}$ cell response resulting from the removal of $\mathrm{KS}$ is associated with increased binding to and endocytosis by APC.

That carbohydrates can inhibit epitope recognition by $\mathrm{T}$ cells, as well as by antibody (31), was revealed recently when oligosaccharides attached to an ovalbumin epitope were found to inhibit $\mathrm{T}$ cell recognition of the epitope (32). Oligosaccharides present on glycoproteins have also been shown previously to protect glycoproteins from proteolytic degradation by preventing accessibility of proteinases to the core protein (33, 34). KS chains in the region of the G1 domain may also protect this region against attack by extracellular proteinases but not by intracellular proteinases since digestion rates within cells were comparable. The presence of KS could inhibit proteolytic cleavage and release of the immunoreactive G1 epitopes by extracellular proteinases.

Our data allow for the possibility that the presence of receptors for KS on APC could negatively influence cellular uptake to APC and presentation to T cells. The CD44 receptor for CS and hyaluronate is present on liver endothelial cells (35) and this or a similar type of receptor could bind KS. The observed enhanced binding of G1 to the cell surface on removal of KS suggests that if such a receptor for KS exists on these cells it may retard G1 binding and/or uptake to APC rather than causing increased endocytosis. Also, KS may inhibit binding if this is via a receptor-mediated binding to the core protein of aggrecan G1 domain.

Heterogeneity in KS content of G1 described earlier (10, 11) may explain why the differences in $T$ cell recognition of native versus KS-depleted G1 are more quantitative than qualitative, and explain why $\mathrm{T}$ cell reactivity to native $\mathrm{G} 1$ increases with concentration. Molecules may exist which do not contain $\mathrm{KS}$ in some domains. It is well known that KS content varies considerably with age and in arthritis, increasing with age (8) and decreasing in disease (36). In the latter case this would favor immune reactions to the G1 domain.

In immature bovine cartilage, $\mathrm{KS}$ is located in the interglobular domain between the G1 and G2 domains $(9,11,37)$. In mature cartilage it is also present in the G1 globular domain in the A, B, and B' subdomains (37). Fetal cartilage is generally lacking or deficient in $\mathrm{KS}$ compared with the adult $(7,8)$. The presence of KS can be viewed as protective against the development of immunity to this region of the molecule even when it is denatured or only partly degraded. This is borne out by our present observation that removal of KS leads to induction of arthritis. Moreover, our earlier observation shows that human adult (3) and bovine (4) PG (rich in KS) depleted of CS could not induce arthritis, whereas human fetal PG (lacking $\mathrm{KS}$ ) depleted of CS could induce arthritis also points to this protection by KS. However, in the present study we show that adult bovine PG from adult cartilage could induce arthritis in some mice but only when KS as well as CS chains are removed. Clearly both CS and KS inhibit production of arthritis, but since only $\mathrm{KS}$ is associated with the $\mathrm{G} 1$ domain, removal of this GAG alone confers on G1 the capacity to induce arthritis.

$\mathrm{CNBr}$ cleavage (mimicking proteolysis in vivo) also produced KS-free peptides bearing the epitopes recognized by these $\mathrm{T}$ hybridomas. This also enhanced the $\mathrm{T}$ hybridoma responses. Since even fixed APC could present these large $\mathrm{CNBr}$ peptides, $\mathrm{T}$ cell hybridomas themselves may mediate further cleavage of larger peptides produced by extracellular proteolysis. Extracellular proteolysis leading to the release of G1 is known to result in the generation of fragments of this molecule which include the Gl globular domain (hyaluronic acid binding region) (38). Clearly, sites of proteolysis would be critical in determining whether fragments are produced bearing $\mathrm{T}$ cell epitopes that do or do not contain $\mathrm{KS}$ and that are small enough to be presented without further proteolysis such as that produced by $\mathrm{CNBr}$. Such extracellular proteolysis could also result in loss of conformation and hence function (hyaluronic acid binding) of the G1 domain as we have shown previously in synovial fluids of patients with arthritis (38). A loss of conformation induced by reduction and alkylation clearly also enhanced $\mathrm{T}$ hybridoma responses to G1. But the removal of KS by keratanase further enhanced the response to the denatured molecule. Thus, loss of conformation and loss of KS can independently enhance $\mathrm{T}$ hybridoma responses and proteolysis would likewise be expected to influence $\mathrm{T}$ cell responses in vivo by producing fragments lacking conformation with or without KS.

Proteolytic cleavage of PG in cartilage often involves a primary cleavage in the interglobular domain between G1 and G2 leading to the release of the majority of the PG molecule $(39,40)$. G1, in association with LP, ordinarily remains bound to hyaluronic acid and is thereby retained and becomes concentrated in the adult extracellular matrix of articular cartilages (41). In chronic rheumatoid arthritis there is likely a similar enrichment of this G1 globular domain in cartilage, as is also observed in synovial fluid $(38,42)$. Whether arthritogenic epitopes may be produced would be determined by the cleavage of core protein which could result in the presence or absence of KS on fragments bearing potentially arthritogenic epitopes recognized by T lymphocytes. Whether these immune responses to aggrecan, which are observed in rheumatoid arthritis in children and adults $(1,2)$, are of importance in the pathogenesis of these diseases remains to be established.

\section{Acknowledgments}

We thank Dr. Peter Neame and Dr. Frank Barry (Shriners Hospital, Tampa, FL) for the amino acid sequence of the G1 domain of bovine aggrecan and information on the attachment points of KS. We thank Jane Wishart for the artwork and Audrey Wheeler for processing this manuscript.

This study was funded by the Shriners of North America (to A.R. Poole), U.S. Public Health Service grants AR34614 and AR21498 (to L.C. Rosenberg), and the UCB Institute of Allergy (to A. Guerassimov).

\section{References}

1. Golds, A.A., I.B.M. Stephen, J.M. Esdaile, H. Strawczynski, and A.R. Poole. 1983. Lymphocyte transformation to connective tissue antigens in adult and juvenile rheumatoid arthritis, osteoarthritis, ankylosing spondylitis, systemic lupus erythematosus and a nonarthritic control population. Cell. Immunol. 82:196-209.

2. Mikecz, K., T.T. Glant, M. Baron, and A.R. Poole. 1988. Isolation of pro- 
teoglycan-specific $\mathrm{T}$ lymphocytes from patients with ankylosing spondylitis. Cell. Immunol. 112:55-63.

3. Glant, T.T., K. Mikecz, A. Arzoumanian, and A.R. Poole. 1987. Proteoglycan induced arthritis in BALB/c mice. Clinical features and histopathology. Arthritis \& Rheum. 30:201-212.

4. Mikecz, K., T.T. Glant, and A.R. Poole. 1987. Immunity to cartilage proteoglycans in $\mathrm{BALB} / \mathrm{c}$ mice with progressive polyarthritis and ankylosing spondylitis induced by injection of human cartilage proteoglycan. Arthritis \& Rheum. 30:306-318.

5. Mikecz, K., T.T. Glant, E. Buzas, and A.R. Poole. 1990. Proteoglycaninduced polyarthritis and spondylitis adoptively transferred to naive (nonimmunized) BALB/c mice. Arthritis \& Rheum. 33:866-876.

6. Banerjee, S., C. Webber, and A.R. Poole. 1992. The induction of arthritis in mice by the cartilage proteoglycan aggrecan: roles of CD4+ and CD8+ T cells. Cell. Immunol. 144:347-357.

7. Glant, T.T., K. Mikecz, P.J. Roughley, E. Buzàs, and A.R. Poole. 1986. Age-related changes in protein-related epitopes of human articular cartilage proteoglycans. Biochem. J. 236:71-75.

8. Roughley, P.J., and R.T. White. 1980. Age related changes in the structures of the proteoglycan subunits from human articular cartilage. J. Biol. Chem. 225:217-224.

9. Leroux, J.Y., A.R. Poole, C. Webber, V. Vipparti, H.K. Choi, L.C. Rosenberg, and S. Banerjee. 1992. Characterization of proteoglycan-reactive $\mathrm{T}$ cell line and hybridomas from mice with proteoglycan-induced arthritis. $J$. Immunol. 148:2090-2096.

10. Bonnet, F., D.G. Dunham, and T.E. Hardingham. 1985. Structure and interactions of cartilage proteoglycan binding region and link protein. Biochem. J. 228:77-85

11. Barry, F.P., J.U. Gaw, C.N. Young, and P.J. Neame. 1992. Hyaluronanbinding region of aggrecan from pig laryngeal cartilage. Amino acid sequence, analysis of N-linked oligosaccharides and location of the keratan sulphate. Biochem. J. 286:761-769.

12. Lowry, O.H., N.J. Rosebrough, A.L. Farr, and R.J. Randall. 1951. Protein measurement with the Folin phenol reagent. J. Biol. Chem. 193:265-275.

13. Tang, L.H., L.A. Rosenberg, A. Reiner, and A.R. Poole. 1979. Proteoglycan from bovine nasal cartilage. Properties of a soluble form of link protein. J. Biol. Chem. 254:10523-10531.

14. Oike, Y., K. Kimata, T. Shinomura, K. Nakazawa, and S. Suzuki. 1980. Structural analysis of chick-embryo cartilage proteoglycan by selective degradation with chondroitin lyases (chondroitinases) and endo- $\beta$-D-galactosidase (keratanase). Biochem. J. 191:193-207.

15. Heinegård, D., and Y. Sommarin. 1987. Isolation and characterization of proteoglycans. In Methods in Enzymology. Chapter 17. Vol. 144. Academic Press Inc., Orlando, FL. 319-372.

16. Poole, A.R., C. Webber, A. Reiner, and P. Roughley. 1989. Studies of a monoclonal antibody to skeletal keratan sulphate. Importance of antibody valency. Biochem. J. 260:849-856.

17. Laemmli, U.K. 1970. Cleavage of structural proteins during the assembly of the head of bacteriophage $\mathrm{T}_{4}$. Nature (Lond.). 227:680-685.

18. Stevens, J.W., Y. Oike, C. Handley, V.C. Hascall, A. Hampton, and B. Caterson. 1984. Characteristics of the core protein of the aggregating proteoglycan from the Swarm rat chondrosarcoma. J. Cell. Biochem. 26:247-259.

19. Caterson, B., J.E. Christner, and J.R. Baker. 1983. Identification of a monoclonal antibody that specifically recognizes corneal and skeletal keratan sulfate: monoclonal antibodies to cartilage proteoglycan. J. Biol. Chem. 258: 8843-8854.

20. Cawston, T.E., and A.J. Barrett. 1979. A rapid and reproducible assay for collagenase using 1-14C acetylated collagen. Anal. Biochem. 99:340-345.

21. Campbell, I.K., E.E. Golds, J.S. Mort, and P.J. Roughley. 1986. Human articular cartilage secretes characteristic metal dependent proteinases upon stimulation by mononuclear cell factor. J. Rheumatol. 13:20-27.

22. Matsudaira, P. 1987. Sequence from picomole quantities of proteins electroblotted onto polyvinylidene difluoride membranes. J. Biol. Chem. 262: $10035-10038$.
23. Kappler, J.W., B. Skidmore, J. White, and P. Marrack. 1981. Antigeninducible $\mathrm{H}-2$ restricted interleukin-2 producing $\mathrm{T}$ cell hybridomas. Lack of independent antigen and $\mathrm{H}-2$ recognition. J. Exp. Med. 153:1198-1214.

24. Mosmann, T.R., H. Cherwinski, M.W. Bond, M.A. Giedlin, and R.L. Coffman. 1986. Two types of murine helper T clone. I. Definition according to profiles of lymphokine activities and secreted proteins. J. Immunol. 136:23482357

25. Abou-Zeid, C., E. Filley, J. Steele, and G.A.W. Rook. 1987. A simple new method for using antigens separated by polyacrylamide gel electrophoresis to stimulate lymphocytes in vitro after converting bands cut from Western blots into antigen-bearing particles. J. Immunol. Methods. 98:5-10.

26. Nakazawa, K., and S. Suzuki. 1975. Purification of keratan sulfateendogalactosidase and its action on keratan sulfates of different origin. J. Biol. Chem. 250:912-917.

27. Unanue, E.R. 1984. Antigen-presenting functions of the macrophage. Anпи. Rev. Immunol. 2:395-428.

28. Neame, P.J., J.E. Christner, and J.R. Baker. 1987. Cartilage proteoglycan aggregates. The link protein and proteoglycan amino-terminal globular domains have similar structures. J. Biol. Chem. 262:17768-17778.

29. Sandy, J.D., C.R. Flannery, R.E. Boynton, and P. Neame. 1990. Isolation and characterization of disulfide-bonded peptides from the three globular domains of aggregating cartilage proteoglycan. J. Biol. Chem. 265:21108-21113.

30. Allen, P.M., and E.R. Unanue. 1984. Differential requirements for antigen processing by macrophages for lysozyme-specific T cell hybridomas. J. Immunol. 132:1077-1079.

31. Fosang, A., and T.E. Hardingham. 1991. I-C-6 epitope in cartilage proteoglycan G2 domain is masked by keratan sulfate. Biochem. J. 273:369-373.

32. Ishioka, G.Y., A.G. Lamont, D. Thomson, N. Bulbow, F.C.A. Gaeta, A Sette, and H.M. Grey. 1992. MHC interaction and T cell recognition of carbohydrates and glycopeptides. J. Immunol. 148:2446-2451.

33. Olden, K., R.M. Pratt, and K.M. Yamada. 1979. Role of carbohydrate in biological function of the adhesive glycoproteinase fibronectin. Proc. Natl. Acad. Sci. USA. 76:3343-3347.

34. Kozarsky, K., D. Kingsley, and M. Krieger. 1988. Use of a mutant cell line to study the kinetics and functions of O-linked glycosylation of low density lipoprotein receptors. Proc. Natl. Acad. Sci. USA. 85:4335-4339.

35. Laurent, T.C., J.R. Fraser, H. Pertoft, and B. Smedsrod. 1986. Binding of hyaluronate and chondroitin sulfate to liver endothelial cells. Biochem. J. 234:653-658.

36. Poole, A.R. 1986. Changes in the collagen and proteoglycan of articular cartilage in arthritis. Rheumatology. 10:316-371.

37. Barry, F.P., L.C. Rosenberg, J.U. Gaw, T. J. Koob, and P.J. Neame 1995. N- and O-linked keratan sulfate on the hyaluronan binding region of aggrecan from mature and immature bovine cartilage. J. Biol. Chem. 270:2051620524.

38. Witter, J., P.J. Roughley, C. Webber, N. Roberts, E. Keystone, and A.R. Poole. 1987. The immunologic detection and characterization of cartilage proteoglycan degradation products in synovial fluids of patients with arthritis. $\mathrm{Ar}$ thritis \& Rheum. 30:519-529.

39. Sandy, J.D., P.J. Neame, R.E. Boynton, and C.R. Flannery. 1991. Catabolism of aggrecan in cartilage explants. Identification of a major cleavage site within the interglobular domain. J. Biol. Chem. 266:8683-8685.

40. Sandy, J.D., C.R. Flannery, P.J. Neame, and L.S. Lohmander. 1992. The structure of aggrecan fragments in human synovial fluid. Evidence for the in volvement in osteoarthritis of a novel proteinase which cleaves the Glu373 Ala374 band of the interglobular domain. J. Clin. Invest. 89:1512-1516.

41. Roughley, P.J., R.J. White, and A.R. Poole. 1985. Identification of a hyaluronic acid-binding protein that interferes with the preparation of high-buoyant-density proteoglycan aggregates from adult human articular cartilage. Biochem. J. 231:129-138.

42. Saxne, T., and D. Heinegård. 1992. Synovial fluid analysis of two groups of proteoglycan epitopes distinguishes early and late cartilage lesions. Arthritis \& Rheum. 35:385-390. 